\title{
Women in the boardroom and their impact on default risk: A pitch
}

\author{
Searat Ali a,1 \\ ${ }^{a} P h D$ Candidate at the Department of Accounting, Finance and Economics, Griffith Business \\ School, Griffith University, Australia
}

\begin{abstract}
This pitch research letter (PRL) applies the pitching template developed by Faff (2015) to an academic project on boardroom gender diversity and default risk. The pitching template helped the pitcher to identify the core elements that form the framework of the research project. The PRL encloses a brief background about the pitcher and pitch, followed by a brief commentary on the pitch and personal reflections of the pitcher on the pitch exercise itself.
\end{abstract}

Keywords: Pitching research; Pitching template; Novice researchers; Women on boards; Default risk, Information asymmetry; Corporate governance

\section{JEL codes: G12, G34}

\section{Introduction}

I am currently a PhD candidate at the Department of Accounting, Finance and Economics (AFE) at Griffith University and my thesis has been under examination since 28 September 2016. My primary field of research is corporate finance and corporate governance. My PhD thesis includes three empirical essays that investigate the influence of corporate governance quality (as measured through board independence) on firm risk such as financial distress or default risk, stock liquidity, and downside and upside risk.

In this pitch research letter (PRL), I apply the pitching template developed by Faff (2015) to a collaborative project on boardroom gender diversity and default risk. This is a 'real' pitch as it relates to an area of research that I have been pursuing since my $\mathrm{PhD}$ thesis submission. For this project, I have received a Publication Assistance Scholarship (PAS) from Griffith Graduate Research School (GGRS). The initial draft of the pitching template was completed and presented on 04 May 2016 at the University of Queensland (UQ) in the 'Research Process in

\footnotetext{
${ }^{1}$ Corresponding author: Department of Accounting, Finance and Economics, Griffith Business School, Griffith University, 170 Kessels Road, Nathan QLD 4111, Australia; tel. (+61) (0)7 3735 7295; Email address: searat.ali@griffithuni.edu.au
}

Acknowledgements: The author thanks Ellie Chapple (the editor) and five anonymous reviewers for their insightful comments and suggestions to improve the quality of pitch paper. The author is grateful to Professor Robert Faff and the PhD students at the 'Research Process in Business' course presentation at the University of Queensland for their helpful comments and discussions, which helped to effectively execute the proposed research project. The author is also thankful to his supervisors, Dr Benjamin Liu and Dr Jen Je Su, and to Dr Shams Pathan, for their advice on improving the research idea. The author is also grateful to Griffith University Postgraduate Students Association (GUPSA) and Jennifer Beale for editing the English and to Griffith Graduate Research School (GGRS) for their Publication Assistance Scholarship (PAS). The author is responsible for any remaining errors. 
Business' course led by Professor Robert Faff, the founder of pitching research. The current draft was prepared on 20 July 2016 for submission to the Accounting Research Journal (ARJ). This is my second formal experience of implementing the pitching template. Given my exposure to pitching research, I have in the personal reflection section highlighted the worth of doing the pitching exercise, the potential adoptability challenge and solutions, the systematic process of learning the pitching template, and the application of the 'rule of three' in pitching research. I believe these reflections would be useful for early career researchers (ECRs).

The remainder of this PRL is organised as follows. Section 2 gives a brief commentary on the completed pitch; Section 3 covers personal reflections on the pitch exercise; the final section provides concluding remarks.

\section{Brief commentary on the pitch}

\section{[Insert Table 1]}

Table 1 presents the completed pitch on the topic of women in the boardroom and their impact on default risk (item $A$ ). The primary research question (item $B$ ) is 'does boardroom gender diversity reduce default risk?’ The key papers (KPs) (item $C$ ) related to the basic research question are those by Sila, Gonzalez, and Hagendorff (2016), Adams and Ferreira (2009), and Gul, Srinidhi, and Ng (2011). These KPs encapsulate the three selection criteria advised by Faff (2017): 1) recently published 2) in top-tier journals 3) by the gurus/experts in the field.

Of these KPs, the most critical paper (KP1) to the primary research idea is that of Sila et al. (2016), who investigate the association between gender diversity and risk-taking in the US. This paper was recently published in the Journal of Corporate Finance (JCF), which is ABDC A* ranked, and the authors are well renowned in corporate governance research. Interestingly, this paper shows that the relationship between women on boards and risk-taking is driven by an endogeneity bias. The addition of women to boards and the impact of this on financial outcomes and parameters, given such inconclusive findings, are still under live debate. My study examining the impact of boardroom gender diversity on one of the most important types of risk (i.e., default risk) will enrich the current regulatory and research debate on the implications of female representation on corporate boards.

The paper of Adams and Ferreira (2009), KP2, is published in the Journal of Financial Economics (ADBC A* ranked). The authors are gurus in gender diversity research. They find that having more women on boards does not necessarily improve financial performance but suggest that their presence may improve the monitoring function of corporate boards. These findings have advanced the gender diversity literature beyond financial performance to other important parameters such as agency cost, earnings quality, and informativeness of stocks. For instance, the paper of Gul et al. (2011), KP3, published in the Journal of Accounting and Economics (ADBC $\mathrm{A}^{*}$ ranked), argues that gender-diverse boards improve the discussion quality at board meetings, increase the ability of the board to make more informed decisions, and provide more rigorous oversight of the transactions, disclosures and reporting of the firms. Gul et al. (2011) find that boardroom gender diversity increases the transparency of the firms and encourages the informativeness of stock prices. It is interesting to extend their paper while investigating the impact of female directors on default risk through the channel of information asymmetry.

The proposed research, inspired by the generic guidelines given in Faff (2017), is motivated (item $D$ ) by three factors: on-going research and policy debate on the benefits of having more women on boards (key stakeholders); the series of corporate collapses that require changes in 
corporate boards (real-world phenomenon); and a lack of empirical research on the boardroom gender diversity as a critical determinant of default risk (gap in the literature).

The remainder of Table 1 outlines the 'answers' to all the required fields from the Faff (2017) template: Idea, Data, Tools, What's New, So What, Contribution, Other Considerations. The material included for all of these is self-explanatory from the pitching template itself, and thus I feel that no further comment is needed here.

\section{Personal reflection on the pitch exercise}

\subsection{Worth doing pitching exercise}

More than a year has passed since I first used the pitching template, in January 2015. At that time, I had completed the second year of my $\mathrm{PhD}$ with limited research output - just one working paper on corporate governance and financial distress (Ali, Liu, and Su 2014). I used the template for the second working paper, on corporate governance and stock liquidity. The paper (Ali, Liu, and Su 2016) was published in Applied Economics (ABDC A ranked) in February 2016 - a year after I completed the pitching template. Interestingly, the related PRL (Ali 2016) was also published, in the Journal of Accounting and Management Information System (JAMIS), which is ABDC C ranked. This experience reminds me of the famous quote 'one bullet, two kills' and strengthens my belief that 'Faff's pitching template facilitates in publishing research papers'. It does so because it simplifies the research process into preliminaries and a '3-2-1 countdown', as well as facilitating timely and quality feedback from time-poor research mentors. Clarity in the research process and timely expert opinion on the working papers are the two ingredients of utmost importance for achieving high quality research publications. ${ }^{2}$

\subsection{Unfamiliarity - A potential adoptability challenge and solution}

After completing the pitching exercise, I realised that the ease with which researchers can adopt the pitching template may first depend on their 'know-how of the template' and then on their 'level of research experience'. The more one knows about the pitching research framework and has research experience, the more one can enjoy the exercise of completing the pitching template.

Since the pitching template is mainly designed for ECRs, I think their first experience of using the template is more challenging due to their unfamiliarity with the underlying philosophy of the pitch items $(\mathrm{A}-\mathrm{K})$ and their limited research experience. The support for overcoming the unfamiliarity challenge received from Professor Robert Faff and the pitch ambassadors, in terms of training novice researchers on the use of pitching template and providing feedback on the completed pitch, is really helpful and valued. ${ }^{3}$ Another promising strategy, I feel, is that if one has to embrace the pitching template as a novice researcher (e.g., PhD student), then it would be more compelling if the supervisor directs this effort. However, there is then a need for training the supervisors to apply the pitch template as a tool for refining the research ideas of novice researchers. One paper in particular, 'Illustrative guide - step by step procedure', with a few others, might provide an icebreaker for research mentors and ECRs to adopt this phenomenal, cost-effective, and value-added research tool. ${ }^{4}$

\footnotetext{
2 The pitch template also helped me and my co-authors to improve the quality of the paper titled "Stock liquidity, corporate governance and leverage: New panel evidence” published in Pacific-Basin Finance Journal (see, Nadarajah, Ali, Liu, and Haung 2016).

${ }^{3}$ As a pitch ambassador, I have provided feedback on several PRLs (e.g., Atif 2016; Nadarajah 2016).

${ }^{4}$ Reverse engineering (RE), where the environment is controlled, is a good strategy for learning the pitching template (see, Faff, Godfrey, and Teng 2016; Faff, Li, Nguyen, and Ye 2016). Hence, novice researchers may start with RE to develop the know-how and confidence in applying it. However, the primary goal is to use the pitching
} 
I also realised that some deadlines, competitions (or symposiums), and incentives can push and motivate ECRs to adopt the pitching template for the very first time. My first pitching exercise was driven by an external deadline and incentive (i.e., travel grant) given by the Securities Industry Research Centre of Asia-Pacific (SIRCA) pitching research symposium. ${ }^{5}$ In the current exercise, with an incentive to publish in a special pitch paper issue in ARJ, I fixed my internal deadlines to reflect my own previous words: “creating one's own deadlines and using the pitching template at any stage of research is helpful to uplift the level of motivation and focus in research” (Ali, 2016).

\subsection{Systematically learning the pitching template}

The pitching template is about refining the research idea rather than generating it. With the research idea as the pre-requisite, use the pitching template as the tool for refining the idea. From my experience of the pitching exercise, I have devised a systematic process of adopting and learning the pitching template for first-time users. I have classified the learning process into two phases: "Foundation (generic)" and "Implementation (specific)".

\section{[Insert Figure 2]}

Figure 2 presents the step-by-step guidelines for systematically learning the pitching template. To develop the foundation and know-how of the pitching template, the starting point is reading the background papers about the pitching template (see e.g., Faff 2015, 2017) ${ }^{6}$ and watching the introductory YouTube videos on pitching research. ${ }^{7}$ To further enhance basic understanding, the exemplary pitching templates on the UQ website are also appropriate material to consult. ${ }^{8}$ It would be useful if one can identify a few pitch examples related to one's research area. Such examples would help the pitcher to learn how others have completed each item of the template. After completing the pitching template, the next step is to read the PRLs published in JAMIS (see e.g., Shahzad 2016), Accounting and Finance (ACFI) (see e.g., Beaumont 2015; Ratiu 2015), and ARJ (see e.g., Sinnewe 2017). In particular, one should pay attention to the pitchers' personal reflections on the pitch exercise, as these reflections are a great source of inspiration and learning. With the foundation developed, the next phase is the implementation: completing one's own pitching template by paying special attention to the advice given by Faff (2017) in 'cues for the pitcher' ${ }^{9}$ The final step is then writing one's own PRL, including one's personal reflection on the pitching exercise, and submitting it to journals such as JAMIS and ARJ for publication. One may also consider participating in 'pitching research competitions' (e.g., the SIRCA's pitching research symposium) to pitch the research idea (see, Faff 2016; Faff, Carrick, et al. 2017) and publishing in 'Pitch of the Week' (PoW) in social media (e.g., LinkedIn and Twitter) to leverage research visibility (see, Faff, Lay, and Smith 2017). ${ }^{10}$

\footnotetext{
template for the embryonic idea, where the environment is relatively uncontrolled and challenging. Therefore, I would love to see an illustrative example (step by step) of the real pitch, broken down into three phases: preparation, writing, and reflection. I believe such an example would attract the 'stubborn' academics to adopt the pitching research template.

${ }^{5}$ https://www.sirca.org.au/2014/11/sirca-pitching-research-symposium-call-for-papers/

${ }_{6}^{6}$ Other related papers include pitching research for engagement and impact (Faff and Kastelle 2016) and fantasy pitching (Faff, Ali, et al. 2016).

${ }^{7}$ Pitching Research - Past, Present and Future available at https://www.youtube.com/watch?v=0u6PX4hPubY/ Pitching Research Webinar May 2016 available at https://www.youtube.com/watch?v=19s2Mear5I\&list=PLQEsMfMAm1vjmoO7sU2Gs34BKRonvc9-H\&index=13/

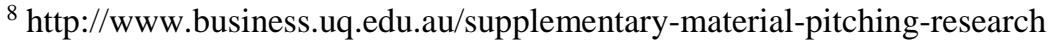

${ }^{9}$ The pitching template can be completed in an online web portal (https://www.pitchmyresearch.com/) with 'cues for the pitcher'

10 https://www.linkedin.com/today/author/0_3VAKjYFj2EGsHOG8b1jeN1?trk=prof-sm/
} 
When the sound know-how (theory) and effective application (practice) of the pitching template have been undertaken, it is time to approach Professor Robert Faff to work as a pitch ambassador disseminating his pitch idea. I have been working as a pitch ambassador for him to promote pitching research in Pakistan under the theme 'reaching the unreachable'. I delivered two pitching research seminars in Pakistan at the University of Punjab and the University of Central Punjab in March 2016. Moreover, I collaboratively worked with him to organize historic webinars for the Imperial College of Business Studies and the University of Haripur in May 2016. ${ }^{11}$ I realised that acting as a pitch ambassador is beneficial because it helps to raise the basic level of understanding of pitching research to a more advanced level. The bottom line is to use the pitching template for mapping and navigating the actual research project.

\subsection{Application of 'rule of three' in the pitching template}

In this pitching template, inspired by Professor Robert Faff, I have extensively applied the 'rule of three'. For instance, the proposed project has three motivations; three KPs with three selection criteria; three hypotheses; three proxies for gender diversity, default risk, corporate governance, and information asymmetry; three data sources; three novel aspects; three key stakeholders of the findings; and three reasons for selecting target journals. ${ }^{12}$ I realized that the rule of three in writing makes things more effective than other quantity. This rule makes the readers more likely to remember the information because having three dimensions offers the smallest amount of information to create a pattern. Given the benefit of this rule, I encourage others to apply it in their research projects.

\section{Conclusion}

This PRL, which is based on Faff (2017) guidelines, covers the basic pitch for a proposed research project on boardroom gender diversity and default risk. It was initially developed for presentation in the 'Research Process in Business' course at the UQ, where its purpose was to receive constructive feedback from Professor Robert Faff and fellow PhD students: feedback that would ultimately enable me to refine my embryonic research idea.

One of the best aspects of the pitching template is that it forces me to think each item over and over, enabling a synthesis of scattered ideas in a systematic way. Given the worth I find from doing the pitching exercise, I strongly encourage others to learn and apply the pitching template as a tool to develop research ideas and to navigate actual research projects.

\section{References}

Adams, R. B., \& Ferreira, D. 2009. "Women in the boardroom and their impact on governance and performance". Journal of financial economics 94: 291-309.

Ali, S. 2016. "Corporate governance and stock liquidity in Australia: A pitch". Journal of Accounting and Management Information Systems 15: 624-631.

Ali, S., Liu, B., \& Su, J. J. (2014). Does corporate governance quality reduce financial distress? New panel evidence from Australia. Paper presented at the 27th Australasian Finance

\footnotetext{
11 https://www.business.uq.edu.au/news/pitching-research-pakistan/

12 The target journals (item K), ACFI and JCF, are selected for three reasons: ranking, scope, and tension. Ranking: ACFI is one of the best and internationally reputed Australian journals, rated A in the ABDC list. Similarly, JCF is a highly reputed international journal and is considered A* in the ABDC list. Scope: Both journals are publishing papers on corporate governance, gender diversity, and default risk. Tension: Recent papers on corporate governance and default risk in ACFI and on gender diversity and risk-taking in JCF find inconclusive results. Moreover, these journals welcome papers using data from countries other than the US, if these offer new insights.
} 
and Banking Conference, Sydney, Australia. Retrieved from http://papers.ssrn.com/sol3/papers.cfm?abstract_id=2481892.

Ali, S., Liu, B., \& Su, J. J. 2016. "What determines stock liquidity in Australia?". Applied Economics 48: 3329-3344.

Atif, M. 2016. "CEO compensation and firm's cash holding: A pitch". Journal of Accounting and Management Information Systems 15: 605-611.

Beaumont, S. J. 2015. "An investigation of the short-and long-run relations between executive cash bonus payments and firm financial performance: a pitch". Accounting \& Finance 55: 337-343.

Faff, R. W. 2015. "A simple template for pitching research". Accounting \& Finance 55: 311336.

Faff, R. W. (2016). Learning from 'Pitching Research' competition winners: Insights and reflections. Retrieved

from https://papers.ssrn.com/sol3/papers2.cfm?abstract_id=2891650

Faff, R. W. (2017). Pitching research. Retrieved from https://papers.ssrn.com/sol3/papers2.cfm?abstract_id=2462059

Faff, R. W., Ali, S., Atif, M., Brenner, M., Chowdhury, H., Cruddas, L., . . . Zhang, K. B. (2016). Fantasy pitching. Retrieved from https://papers.ssrn.com/sol3/papers2.cfm?abstract_id=2782778

Faff, R. W., Carrick, R., Chen, A., Dallest, K., Escobar, M., Foley, G., . . . McCullough, J. (2017). Motivating postgrad research students to pitch their ideas: What have we learned from 'Pitching Research' competitions at UQ? Retrieved from https://papers.ssrn.com/sol3/papers2.cfm?abstract_id=2899942

Faff, R. W., Godfrey, K., \& Teng, J. (2016). Pitching research evolution: An illustrative example on the topic of 'innovation and financial dependence'. Retrieved from https://papers.ssrn.com/sol3/papers2.cfm?abstract_id=2776959

Faff, R. W., \& Kastelle, T. (2016). Pitching research for engagement and impact. Retrieved from https://papers.ssrn.com/sol3/papers2.cfm?abstract_id=2813096

Faff, R. W., Lay, J., \& Smith, M. (2017). PoW! Using social media to leverage research visibility - 'Pitch of the Week' posts in LinkedIn. Retrieved from https://papers.ssrn.com/sol3/papers2.cfm?abstract_id=2894069

Faff, R. W., Li, Y., Nguyen, B. H., \& Ye, Q. (2016). Pitching research: A Pilot experiment with UQ winter scholars. Retrieved from https://papers.ssrn.com/sol3/papers2.cfm?abstract_id=2816233

Gul, F. A., Srinidhi, B., \& Ng, A. C. 2011. "Does board gender diversity improve the informativeness of stock prices?". Journal of Accounting and Economics 51: 314-338.

Nadarajah, S. 2016. "Corporate governance and leverage in Australia: A pitch". Journal of Accounting and Management Information Systems 15: 819-825.

Nadarajah, S., Ali, S., Liu, B., \& Haung, A. 2016. "Stock liquidity, corporate governance and leverage: New panel evidence". Pacific-Basin Finance Journal, Forthcoming.

Ratiu, R. V. 2015. "Financial reporting of European banks during the GFC: A pitch". Accounting \& Finance 55: 345-352.

Shahzad, S. K. 2016. "Private firms' adaptation to climate change within the context of developing countries: A pitch". Journal of Accounting and Management Information Systems 15: 168-177.

Sila, V., Gonzalez, A., \& Hagendorff, J. 2016. "Women on board: Does boardroom gender diversity affect firm risk?". Journal of Corporate Finance 36: 26-53.

Sinnewe, E. 2017. "Is less more? Does integrated reporting lead to a desirable level of reporting conciseness?: A pitch". Accounting Research Journal, forthcoming. 
Figure 1: Mickey Mouse diagram characterizing novelty of my research idea

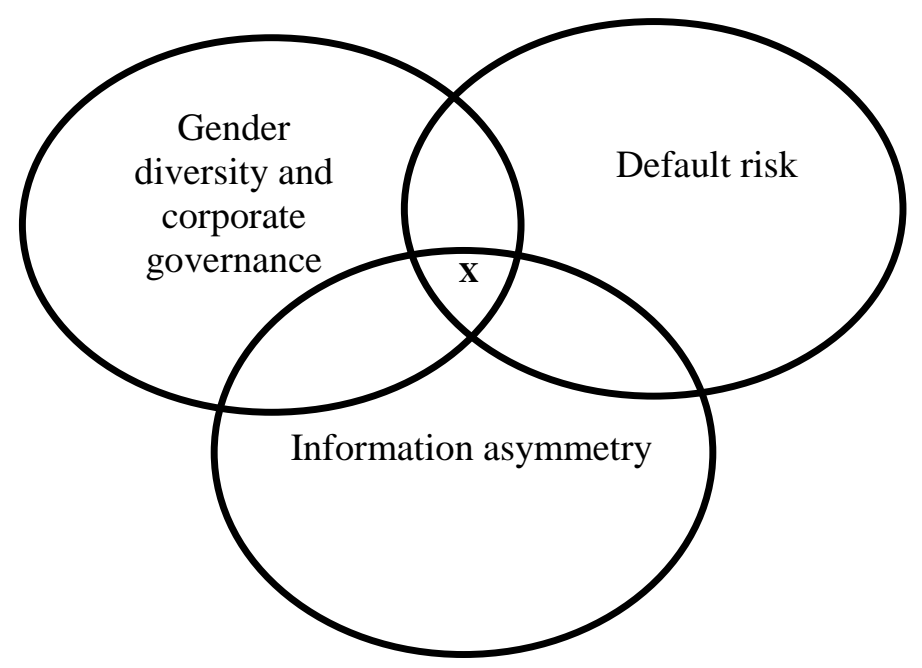

Figure 2: Systematic process of learning to use the pitching template

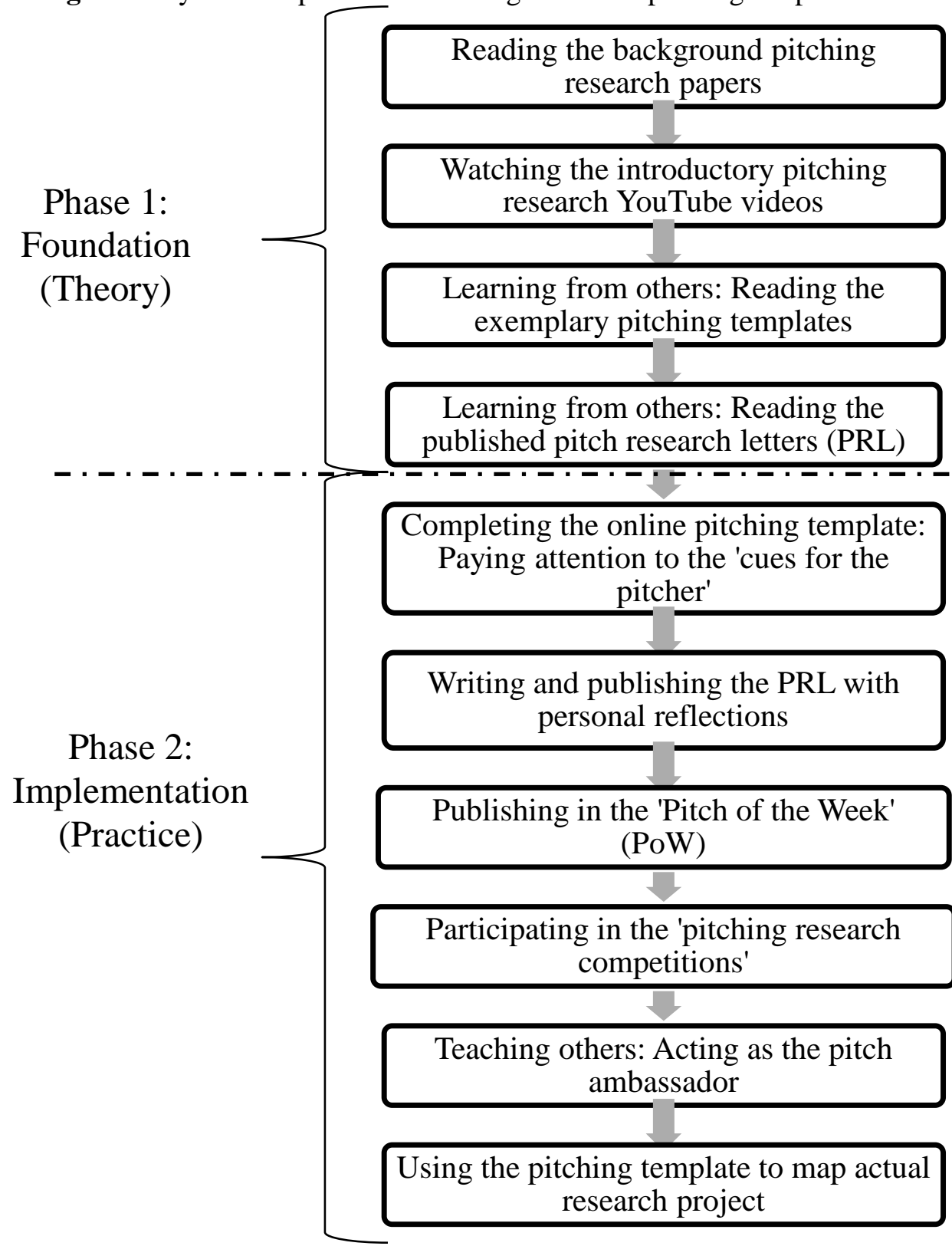


Table 1: Completed 2-page pitch template on boardroom gender diversity and default risk

\begin{tabular}{|c|c|c|c|c|c|}
\hline Pitcher’s Name & Searat Ali & FoR category & Default risk & Date Completed & \begin{tabular}{|l|}
20 \\
2016
\end{tabular} \\
\hline (A) Working Title & \multicolumn{5}{|c|}{ Women in the boardroom and their impact on default risk } \\
\hline & \multicolumn{5}{|c|}{ Does boardroom gender diversity reduce default risk? } \\
\hline (C) Key paper(s) & \multicolumn{5}{|c|}{$\begin{array}{l}\text { Sila, V., Gonzalez, A., Hagendorff, J. 2016. Women on board: Does boardroom } \\
\text { gender diversity affect firm risk? Journal of Corporate Finance. 36, 26-53. } \\
\text { Adams, R. B., Ferreira, D. 2009. Women in the boardroom and their impact on } \\
\text { governance and performance. Journal of Financial Economics. 94, 291-309. } \\
\text { Gul, F. A., Srinidhi, B., Ng, A. C., 2011. Does board gender diversity improve the } \\
\text { informativeness of stock prices? Journal of Accounting and Economics. } 51 \text { (3), } \\
\text { 314-338. }\end{array}$} \\
\hline $\begin{array}{l}\text { (D) } \\
\text { Motivation/Puzzle }\end{array}$ & \multicolumn{5}{|c|}{$\begin{array}{l}\text { With the perceived benefits of women on boards (such as risk aversion, active } \\
\text { monitoring, and novel perspectives and experiences), boardroom gender diversity } \\
\text { has received considerable attention from the regulators (e.g., ASX, 2010) around the } \\
\text { globe in the past few decades. In particular, after the series of corporate collapses } \\
\text { and global financial crisis, an important question has been raised: would the crisis } \\
\text { have happened if more women directors were running corporations? While the } \\
\text { effects of boardroom gender diversity on financial outcomes and parameters have } \\
\text { been widely studied in the literature, its effect on default risk remains largely } \\
\text { unexplored. }\end{array}$} \\
\hline THREE & \multicolumn{5}{|c|}{ Three core aspects of any empirical research project i.e. the "IDioTs" guide } \\
\hline (E) Idea? & \multicolumn{5}{|c|}{$\begin{array}{l}\text { According to agency theory, women directors may improve the effectiveness of the } \\
\text { board in monitoring the opportunistic behavior of management and in mitigating the } \\
\text { information asymmetry between management and shareholders, and are thus likely } \\
\text { to reduce the default risk. Furthermore, according to resource dependence theory, } \\
\text { female directors may bring three benefits to the firm: advice, legitimacy, and } \\
\text { communication channels, which are imperative for the survival of the firm. } \\
\text { MAIN HYPOTHESIS: All else being equal, firms with higher boardroom gender } \\
\text { diversity have a lower level of default risk (Impact hypothesis). } \\
\text { I will also explore two extensions beyond the baseline hypothesis: First, whether } \\
\text { information asymmetry plays the role of a channel between boardroom gender } \\
\text { diversity and default risk (mechanism hypothesis); second, whether the gender- } \\
\text { default linkage is moderated by degrees of governance quality (substitution } \\
\text { hypothesis). The idea is to explore if gender diversity is a substitute for internal or } \\
\text { external governance quality. }\end{array}$} \\
\hline (F) Data? & \multicolumn{5}{|c|}{$\begin{array}{l}\text { SAMPLE: Australia's non-financial firms from } 2008 \text { to } 2013 \text { (because of recent } \\
\text { gender reforms (2010), and 'If not, why not' approach). } \\
\text { DEFAULT RISK (3): Merton (1974) Distance to Default, Credit Default Swap } \\
\text { Spread, and the probability of default. } \\
\text { GENDER DIVERSITY (3): Percentage of women on boards, a presence of at least } \\
\text { one woman on board (dummy variable), and Blau index. } \\
\text { INFORMATION ASYMMETRY (3): Time-weighted quoted spread, Amihud } \\
\text { illiquidity estimate, and turnover adjusted zero-volume days. } \\
\text { INTERNAL GOVERNANCE (1): Self-constructed index based on } 17 \text { objective } \\
\text { criteria from the Horwath report. } \\
\text { EXTERNAL GOVERNANCE (2): Ownership concentration and product market } \\
\text { competition. } \\
\text { DATA SOURCES (3): SIRCA, Morningstar DatAnalysis premium, and } \\
\text { Bloomberg. Databases available at Griffith University. } \\
\text { DATA HANDLING: Name changes while merging data from different sources and } \\
\text { removing outliers etc. } \\
\text { VARIATION: Yes, due to gender reforms in 2010, a good variation within firm } \\
\text { over time is expected. }\end{array}$} \\
\hline
\end{tabular}




\begin{tabular}{|c|c|}
\hline (G) Tools? & $\begin{array}{l}\text { BASELINE REGRESSION MODELS: Pooled OLS, fixed effect and between } \\
\text { effect. } \\
\text { ENDOGENEITY CHECKS: Lagged variables, instrumental variables, generalized } \\
\text { method of moments, propensity score matching and difference in difference. } \\
\text { STATA } 13 \text { (available through Griffith University). }\end{array}$ \\
\hline TWO & Two key questions \\
\hline (H) What's New? & $\begin{array}{l}\text { This is the first study to examine the influence of boardroom gender diversity on } \\
\text { default risk. Moreover, novelty is around both investigating information asymmetry } \\
\text { as a channel between boardroom gender diversity and default risk and examining } \\
\text { substitution effects - most notably gender vs internal and external monitoring } \\
\text { mechanisms. See Figure } 1 \text { for Mickey Mouse/ Venn diagram. }\end{array}$ \\
\hline (I) So What? & $\begin{array}{l}\text { Since the benefits of adding more women to boards is under discussion, knowing } \\
\text { the relationship between gender diversity and default risk will enrich the regulatory } \\
\text { and research debate. One may criticize the risk aversion of the women based on the } \\
\text { principle of 'no risk, no gain'. However, if gender diversity is associated with the } \\
\text { reduction of default risk (as we so conjecture), these findings would be very useful } \\
\text { to advocate the positive outcome (i.e., lower default risk) of the women's risk } \\
\text { aversion. The findings will be useful, when studying the substitution effect between } \\
\text { gender and other internal and external governance mechanisms, for the regulators to } \\
\text { advocate appropriate design of gender diversity in the boardroom. If gender } \\
\text { diversity is inversely related to the default risk, investment communities may } \\
\text { benefit from designing investment strategies toward selecting stocks of firms with } \\
\text { more women on boards in order to reduce the default risk of their portfolios. The } \\
\text { findings would be beneficial for firms (by appointing more women on boards) to } \\
\text { lower their cost of capital through reducing the risk premium originated from the } \\
\text { default risk. }\end{array}$ \\
\hline ONE & One bottom line \\
\hline (J) Contribution? & $\begin{array}{l}\text { The findings of this study will add value to the literature on the effects of } \\
\text { boardroom gender diversity on firm-specific variables (in particular, firm risk) by } \\
\text { providing the first comprehensive and robust evidence on the effects of boardroom } \\
\text { gender diversity on default risk for Australian firms subject to the 'comply or } \\
\text { explain' governance regime. Specifically, this study will, for the first time, bring } \\
\text { together three distinct fields: corporate finance (i.e., gender diversity and } \\
\text { governance mechanisms), asset pricing (i.e., default risk), and market } \\
\text { microstructure (i.e., information asymmetry/stock liquidity). }\end{array}$ \\
\hline $\begin{array}{l}\text { (K) Other } \\
\text { Considerations }\end{array}$ & $\begin{array}{l}\text { COLLABORATION: Yes, either internal or external collaboration is desired to } \\
\text { address endogeneity bias. } \\
\text { TARGET JOURNALS: Accounting and Finance, and Journal of Corporate Finance. } \\
\text { RISK ASSESSMENT: 'No result risk' is high because boardroom gender diversity } \\
\text { is still very low. Similarly, 'Competition risk' is high because many researchers are } \\
\text { following gender diversity research. However, 'risk of obsolescence' is low because } \\
\text { gender diversity is receiving wide attention from regulators in the recent decade, } \\
\text { and this attention is expected to continue. } \\
\text { SCOPE: The scope seems appropriate. } \\
\text { PIPELINE: Examining the effect of boardroom gender diversity on default risk } \\
\text { using international data. }\end{array}$ \\
\hline
\end{tabular}

